\title{
Chemical Analysis and Toxicological Assessment of Sesamum indicum Seed Cake on Albino Rats
}

\author{
Ibironke A. Ajayi*, Ademola I. Adeshina \\ Industrial unit, Chemistry Department, Faculty of Science, University of Ibadan, Ibadan, Nigeria
}

\begin{abstract}
Sesamum indicum L. seed cake was analysed for proximate composition, mineral element content and phytochemical properties after which toxicological assessment was carried out on it. The result of the proximate composition showed that the seed cake contained $8.26 \pm 0.04 \%$ moisture, $28.96 \pm 0.12 \%$ crude protein, $9.58 \pm 0.03 \%$ ash, $13.90 \pm 0.04 \%$ crude fibre, $23.28 \pm 0.02 \%$ fat and $29.91 \%$ carbohydrate. The cake was found to be a good source of mineral elements. Calcium (1.5\%) was the highest, followed by magnesium (0.4\%), phosphorus $(0.06 \%)$, iron $(0.04 \%)$ and lead $(0.02 \%)$. The qualitative phytochemical screening carried out on the seed cake revealed the presence of some secondary metabolites such as flavonoids, alkaloids, saponins, phenol, carbohydrate and steroids. This suggests its usefulness in drug manufacture.

A six-week feeding trial was conducted to assess the effect of sesamum seed cake as dietary replacement of groundnut cake in the diet of albino rats. All diets were formulated to meet the entire nutrient requirement for young albino rats (Rattus norvegius). The performance of the rats fed with sesamum seed cake meal-based diet (test) was compared to rats fed a groundnut cake meal-based diet (control). There were significant differences $(P<0.05)$ in the feed intake, specific growth rate and weight gain between rats fed with test diets and those fed with control diet but there were no significant differences $(P>0.05)$ in the packed volume cell $(P V C)$, haemoglobin (Hb), red blood cell (RBC), white blood cell (WBC), neutrophil, lymphocyte and monocyte between the rats in the test and control groups. The seed cake might be suitable for edible purposes.
\end{abstract}

Key words: Sesamum indicum, seed cake, proximate composition, phytochemical properties, toxicological assessment

\section{Introduction}

Sesame (Sesamum indicum L.), also called beniseed belongs to the Pedaliaceae family of plants and it is cultivated in several countries including the USA, India, China, Burma, Sudan and Nigeria (Abou-Garbia et al., 2000). The seeds which are tiny, flat ovals and measuring about $3 \mathrm{~mm}$ (Oshodi et al., 2010) and high in edible oil, protein and calcium has been used as food for ages (Hui, 1996). In Nigeria, the seeds are fried or used to produce soup for human consumption (Alobo, 2001 and Abu-Jdayil et al. 2002). Uaboi et al. (2008) suggested that fermented Sesame seeds could be used as a soup condiment. Sesame has been valued as a healthy food additive preventing diseases and promoting well-being. Sesame seed consumption appears to increase plasma gamma-tocopherol and enhanced a vitamin $\mathrm{E}$ activity which is believed to prevent cancer and heart disease (Cooney et al., 2001). The Japanese traditionally believe that sesame is very good for health (Namiki, 1990; Namiki, 2007). In addition sesame seeds contain two unique substances, sesamin and sesamolin which belong to a group of special beneficial fibers called ligrians, and have been shown to have a cholesterol lowering effects in humans. It also prevents high blood pressure and increase vitamin E supplies in animals. The plant roots and leaves are used in treating migraine, hypertension, ulcers, constipation, chicken pox and piles (Odugbemi, 2006). The concept of improving intestinal health using cheap and effective nutraceutic agents is presently one of the avenues being exploited for use by medical sciences (Oyetayo, 2009).

The seed has been long regarded in the orient as a health food for increasing energy and prevention of aging (Hajimahmoodi et al., 2008). The seeds are used as a demulcent in respiratory infections, infantile cholera, diarrhoea, dysentery, bowel infections and bladder diseases. The seed powder is useful in amenorrhoea, dysmenorrhoea, ulcers and bleeding piles (Visavadiya and Narasimhacharya, 2008). Afolabi et al. (2001) showed that the bread produced from wheat, beniseed and cassava composite flour had similar baking characteristics in terms of appearance, colour and flavour when compared with white wheat bread with higher protein and fat contents. However, raw sesame seeds contain anti nutrients like oxalate and phytate, which are found in the seed hull (Akonji et al., 2003). These substances can adversely affect mineral bioavailability in human nutrition (Van de Poal, 1990). This study was carried out in order to investigate the chemical constituents and evaluate the effects of toxicity of Sesamum indicum seed cake on albino rats. 


\section{Materials and Methods}

\subsection{Seed Collection}

Sesamum indicum seeds were purchased from a local market in Ibadan, Oyo State, Nigeria. The seeds were separated from undesirable materials such as stones, sand and plant parts, washed with distilled water, airdried at room temperature $\left(25 \pm 2^{\circ} \mathrm{C}\right)$ and grinded into coarse powder by an electric blender and kept in clean plastic cans until use.

\subsection{Extraction of sesame seed oil}

The oil sample was extracted from sesame by soxhlet extraction using N-hexane (British Drug House, London) (Aremu et al., 2006). The resulting slurry was filtered and air dried at room temperature $\left(25 \pm 2^{\circ} \mathrm{C}\right)$ for three days until no traces of solvent could be perceived and stored in a clean container until the commencement of the experiment.

\subsection{Determination of nutritional composition of seed cake and feeds}

The nutritional composition of Sesamum indicum seed cake (SISC) and compounded feeds were analyzed for moisture content, crude protein, crude fat, ash content and crude fibre according to method described by AOAC (1995). Carbohydrate content was calculated by difference. Mineral analysis was also done according to AOAC (1995). All determinations were done in triplicate.

\subsection{Phytochemical analysis of Sesamum indicum seed cake}

Phytochemical analysis for the presence of plant secondary metabolites (alkaloids, glycosides, tannins, terpenes, flavonoids, saponins, steroids and resins) was carried out on SISC using standard procedures (Harborne, 1973).

\subsection{Experimental animals}

Fourteen male Wistar rats (Rattus norvegius) were purchased from the Animal House of the Department of Veterinary Medicine, University of Ibadan, Nigeria; their ages ranged between 10-12 weeks and weighed 90-100g. They were housed in plastic cages containing hard wood chips for bedding in controlled animal house at $\left(25 \pm 2^{\circ} \mathrm{C}\right)$. The animals were allowed to acclimatize in the research laboratory for 2 days before the commencement of the study and were fed with standard livestock pellets (Guinea Feed Nigeria Limited).

\subsection{Animal divisions and feed formulation}

The animals were divided into two groups. Group A (control) consisted of 7 animals and were fed with basel diet for six weeks. The diet composed of maize $2800 \mathrm{~g}$, soy bean $1274.7 \mathrm{~g}$, corn bran $495.6 \mathrm{~g}$, wheat flour $495.6 \mathrm{~g}$, palm kernel cake $495.6 \mathrm{~g}$, groundnut cake $495.6 \mathrm{~g}$, calcium $331 \mathrm{~g}$, salt $55.3 \mathrm{~g}$, and oyster shell $158.2 \mathrm{~g}$ while Group B (test) consisted of 7 animals and were fed with experimental diet for six weeks. The diet composed of maize $2800 \mathrm{~g}$, soy bean $1274.7 \mathrm{~g}$, corn bran $495.6 \mathrm{~g}$, wheat flour $495.6 \mathrm{~g}$, palm kernel cake $495.6 \mathrm{~g}$, SISC 495.6g, calcium 331g, salt 55.3g, and oyster shell 158.2g (Souza et al., 2006). SISC replaced the same amount of groundnut cake in control diet because they have the similar nutritional properties.

\subsection{Blood sample collection from animals}

From each animal, $0.7-1 \mathrm{ml}$ of blood sample was obtained by cardiac puncture method using disposable insulin syringes $(1.0 \mathrm{ml})$, put in eppendorff tube containing EDTA to prevent blood coagulation for haematological studies.

\subsection{Haematological analysis of the blood}

The following blood parameters were determined for each of the blood samples using the standard technique described by Jain, (1986).

\subsubsection{Packed cell Volume}

This was determined by spinning of capillary tube containing blood samples at 25,000 rpm for five minutes after which the value was read on the microhaematocrit graphic render and recorded in percentages.

\subsubsection{Haemoglobin Concentration}

$5.0 \mathrm{ml}$ of Drabkins solution was put into a tube, and then into the spectrophotometer cuvettes, this was used to zero and standardize the spectrophotometer (after it has been stabilized for 30 minutes) before putting the tubes. The reading was taken using absorbance at wavelength of $540 \mathrm{~nm}$ (blue-yellow filter). $20.0 \mathrm{ml}$ of each blood sample was dispensed into $5 \mathrm{ml}$ Darbkins haemoglobin solution, mixed thoroughly and allowed to stand 
for 15 minutes. These were then transferred into the spectrophotometer cuvettes. The value of haemoglobin concentration was recorded using a standard prepared chart.

\subsubsection{White Blood Cells (Leucocytes) Count (WBC)}

The graduated pipette was used to take $0.5 \mu 1$ of the blood sample was also dispensed using $25.0 \mu 1$ automatic micropipette and then mixed thoroughly. The cover slip was fixed on the counting chamber properly. A little amount of the dilute blood was dispensed under the cover slip and left for 3 minutes after which it was mounted on the stage. Counting was done at X40 objects. The leucocytes in the four corner primary squares were counted and the value obtained was multiplied by a factor of 50 to obtain the number of cells in $1 \mu 1$ of blood.

\subsubsection{White Blood Cell Differential}

These are divided into granulocytes and agranulocytes. The granulocytes are further divided into three which are neutrophyl, eosinphyl and basophils. These were counted after staining with Giesma stain and their numbers recorded. The agranulocytes are equally further divided into two, which are lymphocytes and monocytes.

\subsubsection{Red Blood Cells}

$1.0 \mathrm{ml}$ of Red Blood Cells (RBC) fluid was withdrawn with pipette into $5.0 \mathrm{ml}$ bijour bottle. Micropipette was used to take 5.0ul of blood sample and dispensed 1.0ul bijour bottle. Effective mixing was done. Little amount of the dilute blood was dispensed into counting chamber beneath the cover slip. This was allowed to settle down for 3 minutes. Afterwards counting was done at objective. The number of cells in five secondary squares ( 80 tertiary squares) was determined and multiplied by 10,000 . This was accomplished by adding four zeros to the total number of cells counted. This represents number of erythrocytes per ml of blood.

\subsection{Statistical analysis}

Values represented are the means and standard deviations for three replicates. Statistical analysis was carried out by Excel Version 8.0 software. Significance was defined at $\mathrm{P}<0.05$.

\subsection{Proximate analysis of Sesamum indicum seed cake}

\section{Results and Discussion}

The result of the proximate composition of seed cake (Table 1) showed that the moisture content of flour was $8.26 \pm 0.04 \%$ of the dry weight. This value is closely related to the moisture content of legumes which ranged between 7.0 and 11.0\% (Arkroyed and Doughty, 1964). It is also higher than 5.7\% that was reported for cashew nut flour (Aremu et al., 2006) and 5.0-5.5\% for pumpkins (Fagbemi and Oshodi, 1991; Ige et al., 1984). The fat recorded a mean value of $23.28 \pm 0.02 \%$ which is lower than the reported value for pumpkin seeds ranging between 47.9-51.1\% (Fagbemi and Oshodi, 1991; Ige et al., 1984; Asiegbu, 1987) but close to reported value of $23.5 \%$ for soy bean (Paul and Southgate, 1980). Fat is important in diets because it promotes absorption of fat soluble vitamins (Bogert et al., 1994) and is in itself a high energy nutrient. SISC has potential of serving as a source of dietary fat and oils. The protein content of the seed cake which was $28.96 \pm 0.12 \%$ is comparably close to such protein-rich foods as soy beans, cowpeas, pigeon peas, melon, pumpkin and gourd seeds all ranging between 23.1-33.0 \% (Olaofe et al., 1994). It exceeds the FAO recommendation value of $19.8 \%$ (FAO, 1982). Therefore, it can be established that it is likely that defatted seed flour can supply the recommended daily intake of protein for children. Apart from the nutritional significance of proteins as source of amino acids, they play a part in the organoleptic properties of food (Okon, 1983). The crude fibre of the flour is $13.90 \pm 0.04 \%$. Maintenance of intestinal distention for a normal peristaltic movement of the gastrointestinal tract is the physiological role which crude fibre can play. It has been reported by Okon (1983) that a diet low in fibre is undesirable as it could cause constipation and that such diets have been associated with diseases of the colon like piles, appendicitis and cancer. Therefore, a diet having an appreciable amount of dietary fibre could help prevent or ameliorate these conditions. These results on nutrition therefore give an indication that SISC is a rich source of necessary nutrients and energy and is equally capable of supplying the daily nutritional and energy requirements of the body.

\subsection{Proximate composition of feed}

Presented on table 2 is the result of the proximate composition of both the test and control diets. The moisture content for the feed of the test diet was $(13.90 \pm 0.02 \%)$ while that of the control one is $(12.38 \pm 0.09 \%)$. The ash content for both the test and control diets were $14.59 \pm 0.06 \%$ and $16.54 \pm 0.07 \%$ while the crude protein for both are $24.77 \pm 0.33 \%$ and $24.15 \pm 0.13 \%$ respectively; it shows that the SISC contained a high proportion of protein. This crude protein value is comparable to $22.0 \%$ 
reported by Souza et al., (2007). The crude fat value $(3.46 \pm 0.03 \%)$ of the control group is lower than that of the test group $(3.63 \pm 0.09 \%)$.

\subsection{Mineral content of Sesamum indicum seed cake}

The Sesamum indicum seed cake contained significant amount of important minerals (Table 3). The calcium concentration ( $1.5 \%$ dry mater) was the highest, followed in descending order by magnesium $(0.4 \%$ dry mater), phosphorous $(0.06 \%$ dry mater), iron $(0.40 \%$ dry mater $)$ and lead $(0.002 \%$ dry mater). Calcium and magnesium play a significant role in photosynthesis, carbohydrate metabolism, nucleic acids and binding agents of cell walls (Russel, 1973). Calcium assists in teeth development (Brody, 1994). Magnesium is essential mineral for enzyme activity; it also plays a role in regulating the acid-alkaline balance in the body. Phosphorus is needed for bone growth, kidney function and cell growth and in maintaining the body's acid-alkaline balance (Fallon, 2001).

\subsection{Phytochemical analysis}

The result of the phytochemical screening (Table 4) indicated the presence of alkaloids, flavonoids, saponins, steroids, phenol and carbohydrate in the defatted seed flour. The alkaloids are well known to have medicinal properties in animals (Karou et al., 2006). It should be noted that steroids compounds are of importance and interest in pharmacy due to their relationship with such compounds as sex hormones (Okwu, 2001).

\subsection{Feed intake and body weight change}

At the beginning of the rat experiment, the test group rats have the highest average body weight of $81.32 \pm 8.52 \mathrm{~g}$ while the mean value obtained for the control group was $80.65 \pm 7.14 \mathrm{~g}$. As the rats continued to be fed with $14.30 \%$ of SISC, there was increase in size and weight. At the sixth week of the feeding period (Table 5), the test rats fed with $14.30 \%$ of SISC as total replacement for groundnut cake had a higher mean body weight of $173.16 \pm 18.65 \mathrm{~g}$ when compared to the control rats $(159.83 \pm 10.54 \mathrm{~g})$. Sesame indicum seed cake might actually be good as a total replacement for groundnut cake in rat feed because of the rapid weight gained and the good physical appearance of the rats.

\subsection{Blood examination}

PVC (\%) in the blood varied from $(41.71 \pm 4.07)$ to $(43.71 \pm 2.81)$ for all the rats in both groups. Haemoglobin concentration $(\mathrm{mg} / \mathrm{dl})$ of the rats is between $(13.1 \pm 1.59)$ to $(14.41 \pm 1.72)$ for both the test and control groups (Table 6); there seemed to be no difference in most parameters studied in the blood with the exception of lymphocyte, neutrophyl and the blood platelet. Red blood cell count $\left(10^{6} / \mathrm{ml}\right)$ of the control group $(7.05 \pm 0.85)$ was greater than $6.74 \pm 1.20$ of the test group. Eosinphyl value (1.00 \pm 1.00$)$ of the control group is similar to $1.0 \pm 0.86$ value obtained for the test group rats. An analysis of variance showed that there is no significant difference between the two groups. White blood cell count $\left(10^{3} / \mu 1\right)$ of the rats in the control group (4464.29 \pm 1262.84$)$ is less than $4878.57 \pm 1696.53$ obtained for those of the test group.

\section{Conclusion}

Sesamum indicum seed cake is rich in protein and carbohydrate. The mineral element composition of seed cake revealed that it is rich in phosphorus, potassium, magnesium and calcium which are essential minerals for growth. The presence of alkaloids in the cake suggests its usefulness in drug manufacture. The result of the rat experiment showed that there was appreciable weight gain for the rats fed with the seed cake and no mortality was recorded. There were also no significant differences in the haematological parameters of rats from both groups. This is an indication that Sesamum indicum seed cake might be safe for human consumption; it could probably also be used as raw materials for the pharmaceutical and food industries.

\section{References}

[1]. Abou-Garbia, H. A., Shehata, A. A. Y., and Shahidi, F. 2000. Effect of processing on oxidative stability and lipid classes of sesame oil. Food Research International 33: 331-340. http:/dx.doi.org/10.1016/so963-9969 (00)00052.1

[2]. Abu-Jdajil, B., Al-Malah, K., and Asoud, H. 2002. Rheological characterization of milled sesame (Tahineh). Food Hydrocolloids 16: 55-61. http:/dx.doi.org/10.1016/S0268-005X (01) 00040-6

[3]. Afolabi, W. A. O., Oguntona, C. R. B., and Fakunmoju, B. B. 2001. Acceptability and chemical composition of bread from beniseed composite flour. Journal of Nutrition and Food Sciences 31(6): 310-313.

[4]. Akanji, A. M., Ologhobo, A. D., Emiola, I. A., and Oladunjoye, I. O. 2003. Effect of raw and differently processed sesame seeds and performance and nutrition utilization of broiler chickens. Proceedings of the 28th Annual Conference of the Nigerian Society of Animal Production 23: 184-186.

[5]. Alobo, A. P. 2001. Effect of sesame seed flour on millet biscuit characteristics. Plant Food Human Nutrition 56: 195-202. http:/dx.doi.org/10.1023/A.1011168724195

[6]. AOAC (1995). Association of official Analytical chemical in official Methods of Analysis. 13th Ed, Washigton D.C. Pp. 858. 
[7]. Aremu, M. O., Olanisakin, A., Bako, D. A. and Madu, P. C. 2006. Compositional studies and physiochemical characteristics of cashew nut (Anarcadium Occidentale) flour. Pakistan Journal of Nutrition 5 (4): 328-333.

[8]. Asiegbu, J. E. 1987. Some biochemical evaluation of fluted pumpkin seeds. Journal of Science Food and Agriculture 40: 151-155.

[9]. Bogert, J. L., Bag, G.M. and Galloeay, D. H. 1994. Nutrition and physical fitness. International Journal of Food Science and Nutrition 45: 223-230.

[10]. Fagbemi, T. N. and Oshodi, A.A. 1991. Chemical composition and functional properties of full fat fluted pumpkin seed flour. Nigeria Food Journal 9:26-32.

[11]. Food and Agricultural Organization of the United Nation (FAOSTAT) (2010). FAO Statistics Division Database. Available at http://fao.org/ updated on 2nd September 2010.

[12]. Harborne, J.B. (1973). Phytochemical methods: London Chapman and hill Ltd. Pp. 49-188.

[13]. Ige, M. N., Ogunsua, A. O. and Okon, O. L. 1984. Functional properties of the protein of some Nigerian oil seeds: conophor seeds and three varieties of melon seeds. Journal of Agriculture and Food Chemistry 32: 822-825.

[14]. Odugbemi, T. 2006. Outline and pictures of Medicinal plants from Nigeria. University of Lagos Press, Yaba, Lagos, Nigeria. pp 283

[15]. Okon, B. D. 1983. Studies on the chemical composition and nutritive value of the fruit of African star apple. M. Sc. thesis, University of Calabar, Pp. 67.

[16]. Okwu, D. E. 2001. Evaluation of the chemical composition of indigenous spices and flavouring agents. Global Journal of Pure and Applied Science 7 (3): 455-549.

[17]. Olaofe, O., Adeyemi, F. O. and Adediran, G. O. 1994. Amino and acid and mineral composition and functional properties of some oil seeds. Journal of Agricultural Food Chemistry 42: 878-884.

[18]. Oshodi, A. A., Ogunbenle, H. N. Oladimeji, M. O. 2010. Chemical, nutritional, and functional properties of Sesamum radiatum. Medline publication PMIO 10719563

[19]. Paul, A. A. and Southgate, B. A. T. 1980. Mucance and Widdowson's composition of food, 4th edition. Her majesty's stationary office, London. UK. Pp. 227-228

[20]. Souza E. and Sorrels, M.E. 1991. Relationships among 70 North American Oat germplasm: I. cluster analysis using quantitative characters. Crop Science 31: 599-605.

Table 1: Proximate composition of Sesanum indica seed cake

\begin{tabular}{ll}
\hline Parameters $(\%)$ & Mean \pm SD \\
Moisture content & $8.26 \pm 0.04$ \\
Ash content & $9.58 \pm 0.03$ \\
Crude protein & $28.96 \pm 0.12$ \\
Crude fibre & $13.90 \pm 0.04$ \\
Crude fat & $23.28 \pm 0.02$ \\
Carbohydrate & $29.91 \pm 0.16$
\end{tabular}

Values are expressed as mean \pm standard deviation for $n=3$

Table 2: Proximate composition of control and test diets

\begin{tabular}{lll}
\hline Parameters $(\%)$ & Control diet & Test diet \\
\hline Moisture content & $12.38 \pm 0.09$ & $13.90 \pm 0.02$ \\
Crude protein & $24.77 \pm 0.33$ & $24.15 \pm 0.13$ \\
Crude fat & $3.46 \pm 0.03$ & $3.63 \pm 0.09$ \\
Crude fibre & $633 \pm 0.11$ & $7.18 \pm 0.02$ \\
Ash content & $7.22 \pm 0.05$ & $16.54 \pm 0.07$ \\
Carbohydrate & $45.30 \pm 0.43$ & $41.77 \pm 0.12$ \\
\hline
\end{tabular}

Values are expressed as mean \pm Standard deviation for $n=3$

Table 3: Mineral element content of Sesanum indica seed cake

\begin{tabular}{ll}
\hline Metal & \% Composition \\
\hline Calcium & 1.500 \\
Magnesium & 0.400 \\
Iron & 0.040 \\
phosphorus & 0.060 \\
Lead & 0.002 \\
\hline
\end{tabular}

Table 4: Result of phytochemical screening of Sesanum indica seed cake

\begin{tabular}{ll}
\hline TEST & RESULT \\
\hline Saponins & + \\
Tannins & - \\
Flavonoids & + \\
Alkaloids & + \\
glycosides & - \\
Steroids & + \\
Carbohydrates & + \\
Phenol & + \\
\hline
\end{tabular}




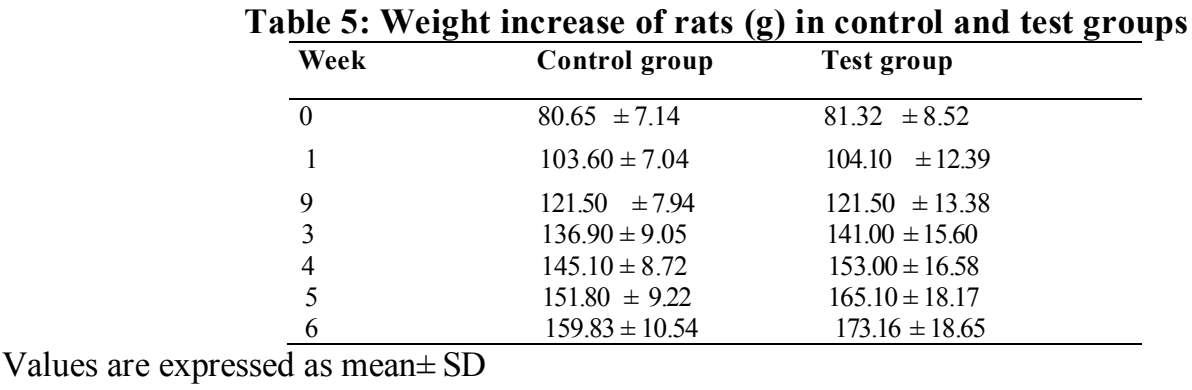

Values are expressed as mean $\pm \mathrm{SD}$

Table 6: Result of haematological analysis of the rats in both control and test groups

\begin{tabular}{lll}
\hline Parameter & Control group & Test group \\
\hline PCV $(\%)$ & $41.71 \pm 4.07^{\mathrm{a}}$ & $43.71 \pm 2.81^{\mathrm{a}}$ \\
$\mathrm{Hb}(\mathrm{mg} / \mathrm{dl})$ & $13.11 \pm 1.59^{\mathrm{a}}$ & $14.41 \pm 1.72^{\mathrm{a}}$ \\
$\mathrm{RBC}\left(10^{6} / \mathrm{\mu l}\right)$ & $7.05 \pm 0.85^{\mathrm{a}}$ & $6.74 \pm 1.20^{\mathrm{a}}$ \\
WBC $\left(10^{3} / \mu 1\right)$ & $4464.29 \pm 1262.84^{\mathrm{a}}$ & $4878.57 \pm 1696.53^{\mathrm{a}}$ \\
Platelet & $81285.71 \pm 19111.20^{\mathrm{a}}$ & $87714.29 \pm 16539.99^{\mathrm{a}}$ \\
Lymphocyte $(\%)$ & $66 \pm 4.51^{\mathrm{a}}$ & $71.71 \pm 6.21^{\mathrm{a}}$ \\
Neutrophyl $(\%)$ & $31.29 \pm 4.68^{\mathrm{a}}$ & $24.29 \pm 5.28^{\mathrm{a}}$ \\
Monocyte $(\%)$ & $1.71 \pm 0.76^{\mathrm{a}}$ & $2.86 \pm 0.90^{\mathrm{a}}$ \\
Eosinophyl $(\%)$ & $0.00 \pm 1.00^{\mathrm{a}}$ & $1.00 \pm 0.82^{\mathrm{a}}$ \\
Total protein & $6.80 \pm 2.57^{\mathrm{a}}$ & $7.57 \pm 0.35^{\mathrm{a}}$ \\
Albumin & $4.64 \pm 0.46^{\mathrm{a}}$ & $4.77 \pm 0.32^{\mathrm{a}}$ \\
Globulin & $3.01 \pm 0.66^{\mathrm{a}}$ & $2.80 \pm 0.26^{\mathrm{a}}$ \\
AG ratio & $1.51 \pm 0.22^{\mathrm{a}}$ & $1.75 \pm 0.91^{\mathrm{a}}$ \\
\hline
\end{tabular}

Values are expressed as mean $\pm \mathrm{SD}$ for $(\mathrm{n}=7$ ) for groups $\mathrm{A}$ and $\mathrm{B}$

Values in the same row with different superscript are significantly different as $\mathrm{P}<0.05$.

Figure 1: Pictogram of feed intake of rats

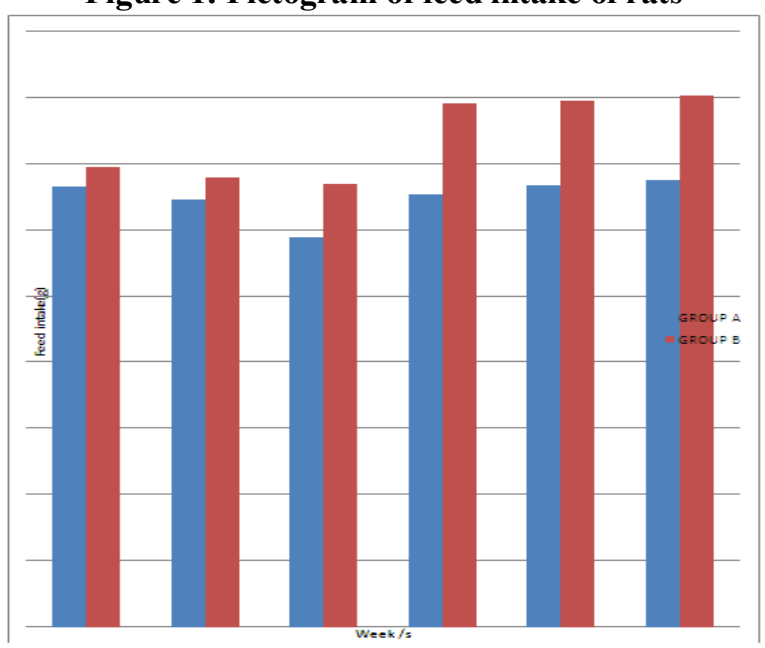

Figure 2: Pictogram of mean weight increase of rats 


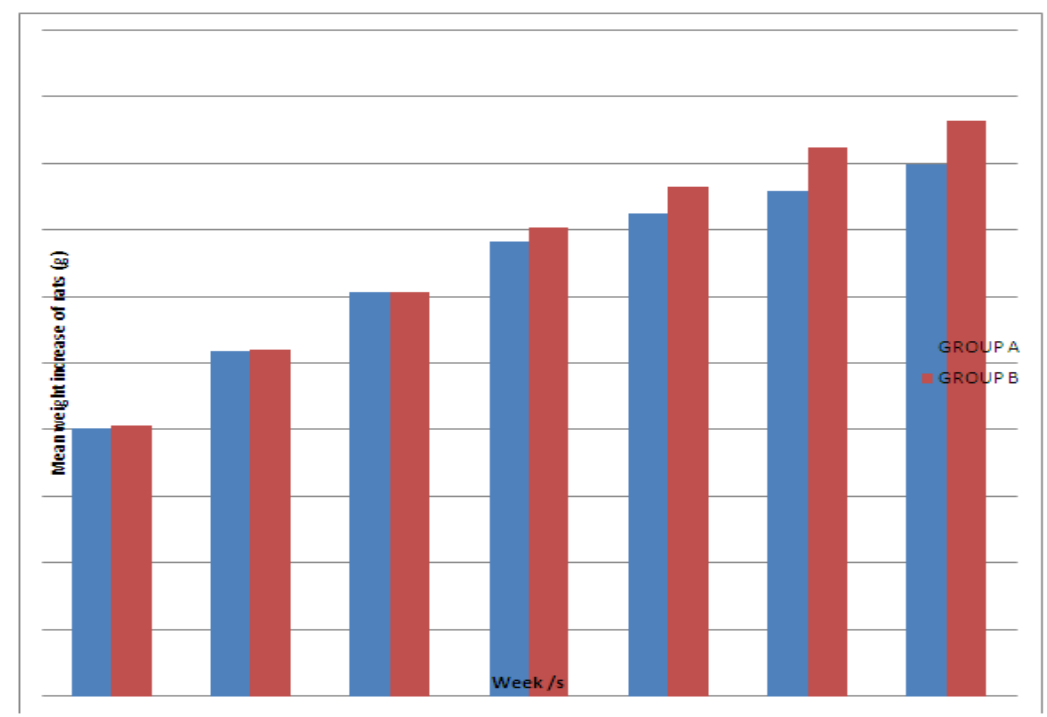

